\title{
Occurrence of Viruses and Associated Grain Yields of Paired Symptomatic and Nonsymptomatic Tillers in Kansas Winter Wheat Fields
}

\author{
Dorith Rotenberg, William W. Bockus, Anna E. Whitfield, Kaylee Hervey, Kara D. Baker, Zhining Ou, \\ Alma G. Laney, Erick D. De Wolf, and Jon A. Appel
}

First, second, third, fourth, fifth, seventh, and eighth authors: Department of Plant Pathology, Kansas State University, Manhattan 66506; sixth author: Department of Statistics, Kansas State University, Manhattan 66506; and ninth author: Kansas Department of Agriculture, Manhattan 66506.

Accepted for publication 2 November 2015.

\begin{abstract}
Rotenberg, D., Bockus, W. W., Whitfield, A. E., Hervey, K., Baker, K. D., Ou, Z., Laney, A. G., De Wolf, E. D., and Appel, J. A. 2016. Occurrence of viruses and associated grain yields of paired symptomatic and nonsymptomatic tillers in Kansas winter wheat fields. Phytopathology 106: 202-210.

Vector-borne virus diseases of wheat are recurrent in nature and pose significant threats to crop production worldwide. In the spring of 2011 and 2012, a state-wide sampling survey of multiple commercial field sites and university-managed Kansas Agricultural Experiment Station variety performance trial locations spanning all nine crop-reporting regions of the state was conducted to determine the occurrence of Barley yellow dwarf virus-PAV (BYDV-PAV), Cereal yellow dwarf virus-RPV, Wheat streak mosaic virus (WSMV), High plains virus, Soilborne wheat mosaic virus, and Wheat spindle streak mosaic virus using enzyme-linked immunosorbent assays (ELISA). As a means of directly coupling tiller infection status with tiller grain yield, multiple pairs of symptomatic and nonsymptomatic plants were selected and individual tillers were tagged for virus

species and grain yield determination at the variety performance trial locations. BYDV-PAV and WSMV were the two most prevalent species across the state, often co-occurring within location. Of those BYDV-PAV- or WSMV-positive tillers, $22 \%$ and $19 \%$, respectively, were nonsymptomatic, a finding that underscores the importance of sampling criteria to more accurately assess virus occurrence in winter wheat fields. Symptomatic tillers that tested positive for BYDV-PAV produced significantly lower grain yields compared with ELISA-negative tillers in both seasons, as did WSMV-positive tillers in 2012. Nonsymptomatic tillers that tested positive for either of the two viruses in 2011 produced significantly lower grain yields than tillers from nonsymptomatic, ELISA-negative plants, an indication that these tillers were physiologically compromised in the absence of virus-associated symptoms. Overall, the virus survey and tagged paired-tiller sampling strategy revealed effects of virus infection on grain yield of individual tillers of plants grown under field conditions and may provide a complementary approach toward future estimates of the impact of virus incidence on crop health in Kansas.
\end{abstract}

Viruses are some of the most economically important pathogens infecting wheat globally (Banks et al. 1995; Budge et al. 2008; Campbell et al. 1975; Herbert et al. 1999; McKirdy et al. 2002; Price et al. 2010; Shahwan and Hill 1984; Vallega et al. 2003; Velandia et al. 2010). Losses attributed to wheat-infecting viruses occur due to reductions in plant stands, water-use efficiency, plant vigor, and production of grain and forage. In the Great Plains, including Kansas, the wheat streak mosaic, barley yellow dwarf, and soilborne and spindle streak complexes are the most important virus diseases of wheat, all of which are dependent on a vector for transmission. The epidemiology of wheat-infecting viruses of the Great Plains is complex and these viruses are often found in perennial grasses (natives and weeds) that may serve as reservoirs of viruses and vectors for annual wheat crops (Garrett et al. 2004). The repertoire of effectual control strategies for viruses is limited to avoidance strategies (cultural practices) and genetic resistance. To date, genetic resistance is the most reliable and effective means for combating plant viruses; however, there are few commercially available resistant lines for several of the viruses affecting hard winter wheat in Kansas.

The wheat streak mosaic (WSM) complex is comprised of Wheat streak mosaic virus (WSMV, family Potyviridae, genus Tritimovirus), Triticum mosaic virus (TriMV, family Potyviridae, genus

Corresponding author: D. Rotenberg; E-mail address: drotenbe@ksu.edu
Poacevirus), and High plains virus (HPV, pending classification in the genus Emaravirus). All are vectored by the wheat curl mite (WCM, Aceria tosichella Keifer). In 2006, a record year for WSM incidence, Kansas growers suffered an estimated 7\% yield loss (Appel et al. 2014). There are very few Kansas varieties with WSM resistance (De Wolf et al. 2014) and resistance to the mite is also lacking. A survey of northwestern Kansas hard winter wheat fields in 2008 and 2009 revealed that WSMV had the highest occurrence compared with TriMV and HPV (Seifers et al. 2010). Economic losses associated with WSM in wheat-cropping systems are attributed to reduced forage production and grain yields. Additionally, WSM significantly reduces root development and water uptake resulting in additional economic losses due to reduced water-use efficiency (Velandia et al. 2010; Price et al. 2010).

The barley yellow dwarf (BYD) complex is found worldwide (Lister and Ranieri 1995; Liu et al. 2007; Pakdel et al. 2010; Svanella-Dumas et al. 2013) and is one of the most economically damaging grain diseases caused by viruses (Miller and Rasochová 1997). BYD is a general description of the disease caused by infection of one or more virus species classified in the family Luteoviridae that infect plants in the family Poaceae and are transmitted in a persistent manner by aphids. There are more than six different virus species in the genera Luteovirus and Polerovirus that are known to cause BYD symptoms (Domier 2012). The two virus species thought to predominate in Kansas wheat crops are Barley yellow dwarf virus (BYDV)-PAV (family Luteoviridae, genus Luteovirus), transmitted by the bird cherry oat aphid (Rhopalosiphum padi) and the green bug (Schizaphis graminum), and Cereal yellow dwarf virus (CYDV)-RPV (family Luteoviridae, genus Polerovirus), 
transmitted by $R$. padi (W. Bockus, unpublished data). In Kansas, BYD has been a recurrent and economically costly problem. Historically, annual losses attributed to BYD in Kansas on a 20-year average are approximately $1 \%$ (Appel et al. 2014). These estimates are conservative loss estimates based on visual surveys of disease incidence, severity, and distribution in commercial fields across the state; however, in early-planted winter wheat when aphid populations are prevalent, losses on susceptible cultivars averaged $49 \%$ over a 7-year period (Gaunce and Bockus 2015).

The third most important group of viral pathogens of Kansas wheat are the soilborne viruses, Soilborne wheat mosaic virus (SBWMV, family Virgaviridae, genus Furovirus) and Wheat spindle streak mosaic virus (WSSMV, family Potyviridae, genus Bymovirus), transmitted by a parasitic plasmodiophorid vector (Polymyxa graminis). Several commercially available cultivars have durable resistance to these viruses (Bockus et al. 2001), but if new strains of virus emerge, as documented for soilborne viruses infecting beets (Liu et al. 2007), the losses to these viruses could be severe. Prior to the deployment of genetic resistance, this was the most important disease complex in Kansas and responsible for an average $4 \%$ yield loss (Bockus et al. 2001). There are no alternative control strategies for these viruses, and they and their vector can persistent in the soil for many years (Kanyuka et al. 2004).

Historical and current annual wheat disease loss estimates based primarily on visual assessment of symptomology indicate that plant viruses are a chronic threat to wheat production in Kansas. Characterization of the occurrence, statewide distribution, and species composition of viruses of economic importance to Kansas growers are requisite to developing integrated disease management strategies suitable for Kansas growing conditions along a marked east-to-west precipitation (Prism precipitation maps: http://www. wrcc.dri.edu/precip.html) and south-to-north temperature gradients (Lauenroth and Burke 1995). The goal of this project was to conduct a 2-year statewide sampling survey of symptomatic and nonsymptomatic winter wheat plants in multiple commercial fields and replicated Kansas Agricultural Experiment Station (KAES) variety performance trial locations across the nine crop-reporting regions of the state. In an effort to provide a more direct estimate of the contribution of natural virus infection on grain yields of individual heads, pairs of symptomatic and nonsymptomatic tillers from plants in close proximity were tagged at variety performance trial locations to couple virus occurrence with tiller grain yield. This study presents a sampling-dependent estimation of the prevalence of agronomically important wheat viruses in Kansas and introduces a pairwise-sampling regime for direct assessment of the association between virus infection, visual symptoms, and individual tiller yields.

\section{MATERIALS AND METHODS}

Winter wheat field survey coverage. The occurrence of wheat viruses in the nine crop-reporting districts in Kansas (http:// www.nass.usda.gov/Statistics_by_State/Kansas/Publications/ District_Map/distmap.htm) was determined in the spring of the 2010-2011 and 2011-2012 growing seasons by sampling two types of field sites: the KAES winter wheat variety performance trials (Lingenfelser et al. 2011) and commercial growers' fields. The established variety performance trials are annually replicated experimental sites across the state that serve to inform growers about the performance of commercial and experimental varieties using best-management practices under various environmental and growing conditions typically experienced in the region.

Wheat tiller head-tagging for virus and yield determination at variety performance trial locations. In spring 2011, soon after heading (Feekes 10.5) (9 to 26 May), 15 variety performance trial locations (one per county) were visually scouted for characteristic leaf symptoms associated with virus infection, i.e., yellow, orange, red, purple discoloration, and/or streaking or mosaic patterns on leaves. Within the border rows along the perimeter of each of the performance trials, 20 pairs of symptomatic (S) and nonsymptomatic (NS) plants were randomly selected within a $30-\mathrm{m}^{2}$ region closest to the edge of the plots. The S-NS pairs were within 0.3 to $0.5 \mathrm{~m}$ apart, and one S tiller head and one NS tiller head of the pair was tagged with colored lab tape and leaves were sampled for virus determination at time of tagging. Each pair of SNS plants was considered one replicate-block (20 per location), serving as the blocking factor for the symptom fixed effect (S versus NS). Identities of the variety of each pair within the sampling location was undetermined; however, selecting heads from plants in close proximity within the external border rows ensured that $\mathrm{S}$ and NS plants of any given pair were the same variety at any given variety performance trial location.

In spring 2012, S-NS paired tillers from 11 of the 15 variety performance trial locations visited the previous season plus two additional trial locations ( 13 in total) were tagged and sampled from 16 April to 8 May in the same manner as described above, with the exception that two widely used hard red winter wheat cultivars in Kansas, i.e., Art and Everest, were specifically targeted within the performance trial sites. In Kansas fields, the cultivar Art is highly susceptible to BYDV, moderately susceptible to WSMV, and resistant to SBWMV and WSSMV, while Everest is classified as moderately resistant to BYDV, moderately susceptible to WSMV, and resistant to the two soilborne viruses (De Wolf et al. 2014). At each location, the fourth block of the established performance trial served as the site of the survey, and each variety test plot was 2-m wide by 8-m long. Ten S-NS pairs of heads were selected and tagged, and leaves were sampled for each of the two varieties plots, providing 20 pairs per location. For two of the locations (Ellis and Pawnee counties), a significant stripe rust epidemic had occurred by the fully headed stage making it impossible to determine whether leaves were symptomatic or nonsymptomatic for virus infection. As such, $20 \mathrm{~S}-\mathrm{NS}$ pairs of Art tillers were selected and sampled for virus determination only from a surrounding field.

Commercial growers' fields. To capitalize on the on-going statewide wheat disease surveys conducted annually since 1976 through cooperative efforts between Kansas Department of Agriculture and Kansas State University Plant Pathology wheat extension pathologists, S and NS plants were sampled from commercial field sites on regular disease scouting routes taken from the southwest to northeast corners of the state. In the 2010-2011 season, leaf samples were collected from 38 counties between 28 March and 8 June 2011, and in the following season, samples were collected from 18 counties between 1 March and 23 May 2012. In total, 41 different counties were visited during the two consecutive seasons of the survey. Attempts were made to collect tillers from S and NS plants in the same manner as described for the variety performance trial locations for virus testing only; however, sampling intensity varied across commercial sites and were fewer in number ( 2 to 16 samples per county).

Leaf tissue sampling and virus detection. Individual samples consisted of the flag-minus-one (penultimate) and flagminus-two leaves of head-tagged tillers. Leaves were removed and placed into small Zip-lock bags and stored on ice in a cooler for no more than 2 days until they arrived at the laboratory for processing. Samples were stored at $6^{\circ} \mathrm{C}$ for no more than 5 days upon receipt in order to process sets of samples in batches weekly. For each sample, $500 \mathrm{mg}$ of leaf tissue was subsampled with scissors dipped in $10 \%$ household bleach for $10 \mathrm{~s}$ followed by $20 \mathrm{~s}$ in distilled water to decontaminate between samples. For $\mathrm{S}$ samples, care was taken to sample symptomatic tissue, however avoiding excessive necrotic tissue. Using Agdia Pathoscreen Kits (Agdia Inc., Elkhart, IN) in a 96-well microtiter plate format following the manufacturer's protocol, triple antibody sandwich (TAS) enzyme-linked immunosorbent assay (ELISA) was performed to detect BYDV-PAV, CYDV-RPV, and SBWMV and double antibody sandwich (DAS)ELISA was performed to detect WSMV, HPV, and WSSMV, with all 
incubation steps performed overnight at $6^{\circ} \mathrm{C}$. The subsampled tissue was ground in $1 \mathrm{ml}$ of general extract buffer (GEB) using a tabletop rolling tissue grinder. A Titertek Multiskan Plus (Titertek Inc., Huntsville, AL) plate reader set at $\lambda=405 \mathrm{~nm}$ was used to determine absorbance at $30-\mathrm{min}$ readings for HPV, WSMV, WSSMV, and SBWMV and 3-h readings for BYDV-PAV and CYDV-RPV. Samples were determined to be positive for virus at three times the average absorbance of the negative controls included on each plate.

Tiller grain yield determination. In 2011, tagged heads from $\mathrm{S}$ and NS paired plants were harvested on 13 to 20 June from 11 of the 14 variety performance trial locations (Franklin, Labette, Clark, Finney, Scott, Thomas, Ellis, Ellsworth, Saline, Mitchell, and Riley counties). Similarly in 2012, heads were harvested on 23 to 31 May from 11 of the 13 locations where Art and Everest were both available for tagging (Finney, Franklin, Labette, McPherson, Mitchell, Reno, Republic, Riley, Saline, Sumner, and Thomas counties). At maturity, heads were collected and transported back to the laboratory. Individual heads were threshed with an electricpowered head thresher (Precision Machine Co., Inc., Lincoln, NE) and grain weights for each head determined.

Statistical analyses. Virus occurrence. Fisher's exact tests of independence were performed on $2 \times 2$ contingency tables using SAS v.9.3 (SAS Institute, Cary, NC) PROC FREQ to determine the statistical significance of the association between (i) type of managed site (commercial versus variety performance trial sites) and plant infection status (+/-) regardless of symptom status for each virus species, (ii) virus species (BYDV-PAV versus WSMV) and plant infection status (+/-) regardless of symptom status for each type of managed site separately, and (iii) type of managed site and plant infection status (+/-) for BYDV-PAV or WSMV for S or NS plants separately. For infection status (categorical column variable), the number of ELISA-positive and ELISA-negative plants were tabulated for each categorical row variable in the analysis. Two-sided $P$ values were used to determine the decision of hypothesis tests with significance level of 0.05 .

Yield response models including variety performance trial location, cultivar, and symptom status. All statistical analyses were performed with SAS v.9.3 using generalized linear mixed model analysis with PROC GLIMMIX to accommodate the nonnormal distribution of the grain yield data in positive numeric scale and associated residuals in the data sets. Gamma distribution was determined to best fit the yield models with log link function, therefore it was used to fit models and test hypotheses regarding yield. The design of the experiment had a fixed treatment factor of field location. Based on our paired sampling strategy (individual wheat heads from NS and S plants in close proximity) at each location, the experimental units for the location effect were heads. Further, pairs of heads at each location served as the random blocking factor for the fixed symptom effect, such that the next layer of treatment structure was based on a randomized complete block design. For the 2011 yield data, the statistical model included two fixed treatment factors, i.e., location, and symptom status (NS, S) nested within location, i.e., symptom (location), with a RANDOM INTERCEPT statement specifying heads as experimental units by setting SUBJECT = head (location). For yield data from 2012, the model included an additional fixed factor, i.e., cultivar and an interaction term location $\times$ cultivar. As a consequence, symptom status was nested within location and cultivar, i.e., symptom (location cultivar), and experimental units were head (location cultivar). Tukey-Kramer adjusted $P$ values for multiple tests were computed posthoc to determine significance of hypotheses tests on mean yields for main effects locations, cultivars (2012), and simple effects symptom status (S versus NS) within each location.

Yield response model including infection symptom status. A simple one-way design was used to test the null hypothesis that mean yields were similar among four possible categories of plants surveyed with regards to symptom status and infection status. Yield

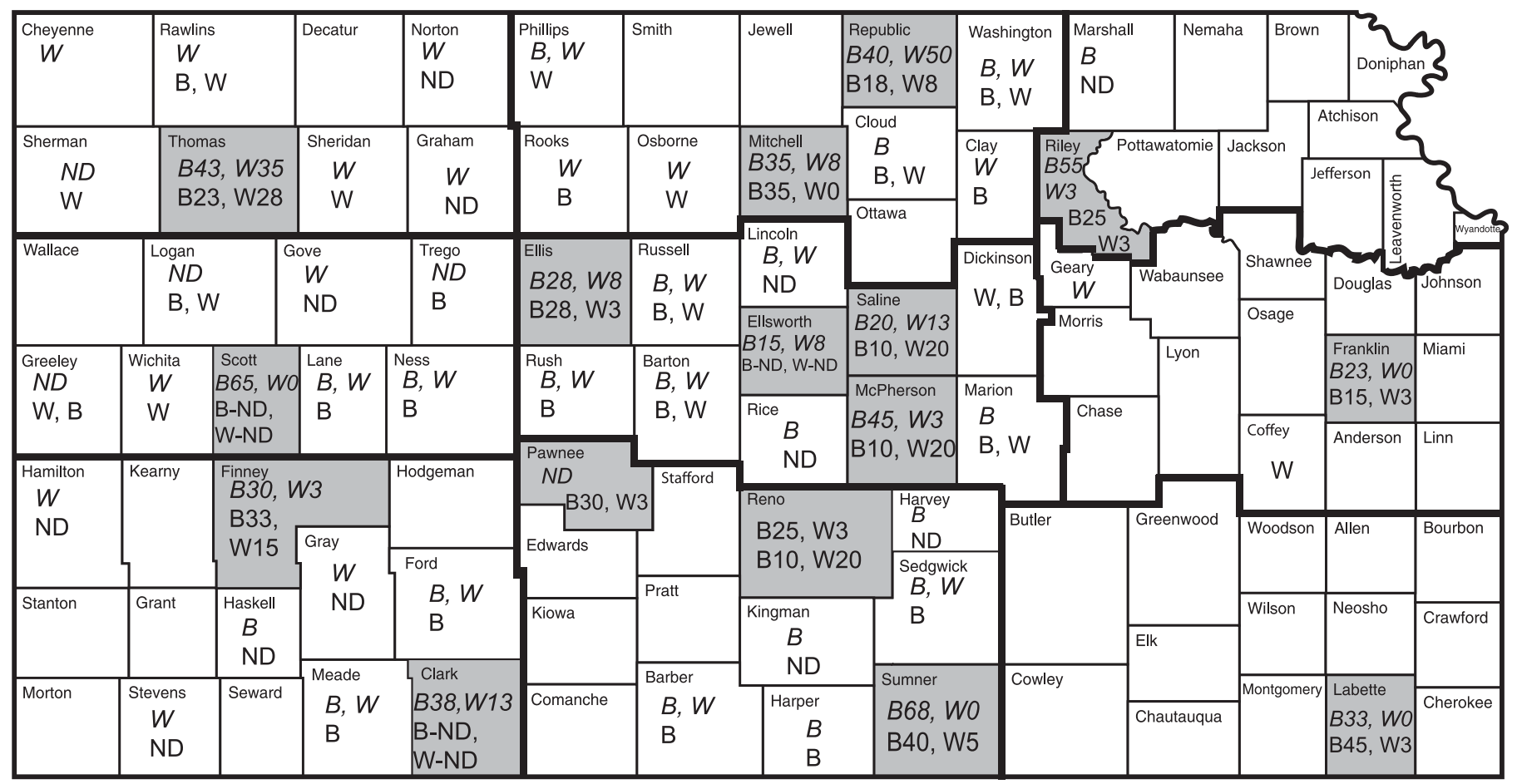

Fig. 1. Regional occurrence of Barley yellow dwarf virus-PAV (BYDV-PAV) and Wheat streak mosaic virus (WSMV) in Kansas. The nine crop-reporting regions are delineated by bold boundary lines. Counties shaded in gray indicate Kansas Agricultural Experiment Station variety performance trial locations; $\mathrm{B}=\mathrm{BYDV}-\mathrm{PAV}, \mathrm{W}=\mathrm{WSMV}, \mathrm{ND}=$ not determined; numbers following the letters $\mathrm{B}$ and $\mathrm{W}$ indicate the proportion of infected plants as determined by enzymelinked immunosorbent assay for BYDV-PAV and WSMV, respectively. Italicized and normal font signifies the 2011 and 2012 wheat survey, respectively. Commercial sites depict the presence or absence of BYDV and WSMV since sampling intensity was less extensive and variable (2 to 16 samples per county per year) at these sites. 
data were pooled for all variety performance trial locations and partitioned into four categories: (i) nonsymptomatic, ELISAnegative (NS-N), (ii) symptomatic, ELISA-negative (S-N), (iii) nonsymptomatic, ELISA-positive (NS-P), and (iv) symptomatic, ELISA-positive (S-P). The model specified in PROC GLIMMIX included only one factor that was created by combining symptom status and infection status, i.e., category, best fit to gamma distribution, and LSMEANS and Tukey-Kramer corrected $P$ values were computed to contrast pairs of categories posthoc.

Association between grain yields and BYDV or WSMV infection. Generalized linear model analysis (implemented in PROC GLIMMIX) was performed to determine the effect of virus infection status on yield. Data were pooled for all variety performance trial locations and plants were assigned 0 or 1 , where $0=$ no virus detected from the panel of six virus species (ELISA-negative) and $1=$ infected with virus (ELISA-positive). Pooled data sets were generated and analyzed separately for BYDV and WSMV, and plants that harbored both virus species were not included in the analysis. The GLIMMIX procedure included one factor, i.e., BYDV or WSMV infection (0 or 1), best fit to gamma distribution, and $P$ values were computed.

Cultivar effect on BYDV and WSMV occurrence and association between yield and infection. Fisher's exact test of independence was performed on pooled variety performance trial data to determine the statistical significance of the association between cultivar (Art and Everest) and occurrence of virus (number of ELISA-positive versus number of ELISA-negative). To examine the effect of virus infection status ( 0 or 1 ) on yield for each cultivar, a GLIMMIX procedure including two factors, cultivar and virus infection status, and their interaction term (cultivar $\times$ infection status) was performed. Hypothesis tests were performed as described above.

\section{RESULTS}

Occurrence of six virus species. Both BYDV-PAV and WSMV were widely distributed across the wheat-growing regions of the state in both seasons (Fig. 1). BYDV-PAV was found in all surveyed regions in both seasons, with "hot spots" in Sumner (south-central) and Scott counties (west-central) in 2011 and in Labette county (southeastern) in 2012. Similar to B YDV-PAV, WSMV was found in all surveyed regions of the state in 2012; however, it was not detected in samples from Labette County (southeastern) in 2011. WSMV occurrence was highest in Republic County (north-central) in 2011, and in Thomas County (north) in 2012. The two soilborne viruses (WSSMV and WSBMV) tended to be localized to the northeastern growing region of the state while HPV was found only in the western and central regions of the state in both seasons (data not shown). One difference between the two seasons was little $(0.1 \%$, north central) to no detection of CYDVRPV across the state in 2012 compared with 2011 (3.4\%, southcentral; $1.2 \%$, north-central).

The proportion of ELISA-positive tillers for each virus tested is shown in Figure 2. Overall, more than half of the plant samples collected from variety performance trials and commercial fields were infected with at least one virus species in 2011 , and $44 \%$ were infected in 2012. Of the six virus species in the test panel, BYDVPAV and WSMV were the two most prevalent species in 2011 (37 and $16 \%$, respectively) and 2012 (27 and $15 \%$, respectively). In general, the overall proportion of BYDV-PAV- and WSMV-positive plants for commercially managed sites were comparable $(2011: P=$ 0.35 ; 2012: $P=0.07$ ); however, in the variety performance trials, BYDV-PAV was more prevalent than WSMV $(2011: P=7.3 \times$ $\left.10^{-37} ; 2012: P=1.3 \times 10^{-13}\right)$. Examination of virus species occurrence by site type revealed that WSMV was more prevalent in commercial growers' fields compared with variety performance trial fields in both seasons (2011: $P=1.7 \times 10^{-23} ; 2012: P=6.6 \times$ $10^{-25}$ ) and that the soilborne viruses (SBWMV and WSSMV) cooccurred in commercial sites and were detected in only 1 sample
(WSSMV) from the variety performance trial locations. Occurrence of BYDV-PAV was comparable between the two types of managed sites in $2011(P=0.49)$, however appeared to be more prevalent at commercial sites than variety performance trial locations in 2012 $(P=0.008)$.

Several trends emerged regarding the virus infection status of NS and S tiller samples. One, a considerable proportion of NS tillers sampled from variety performance trials or commercial fields tested positive for at least one virus species in the survey panel (Table 1),

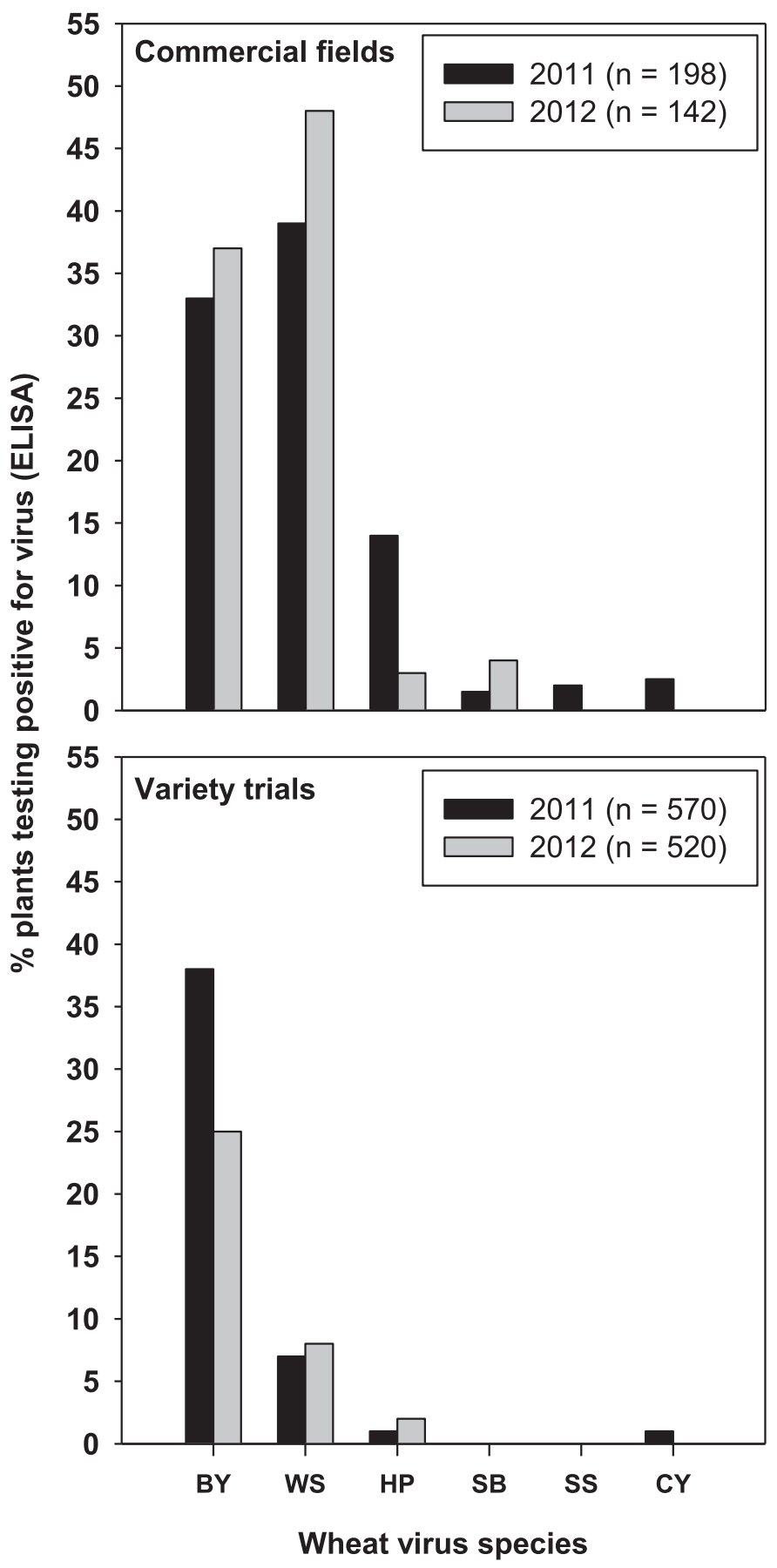

Fig. 2. Occurrence of Barley yellow dwarf virus-PAV (BYDV-PAV), Wheat streak mosaic virus (WSMV), High plains virus (HPV), Soilborne wheat mosaic virus (SBWMV), Wheat spindle streak mosaic virus (WSSMV), and Cereal yellow dwarf virus-RPV (CYDV-RPV) in commercial fields and in Kansas Agricultural Experiment Station variety performance trials in two consecutive winter wheat seasons. BY = BYDV-PAV, WS = WSMV, HP = $\mathrm{HPV}, \mathrm{SB}=\mathrm{SBWMV}, \mathrm{SS}=\mathrm{WSSMV}$, and CY = CYDV-RPV. 
and for both years combined, the overall frequency of these virus-positive NS plants was greater at commercial sites compared with the variety performance trial sites for both seasons (2011: $\left.P=2.5 \times 10^{-7} ; 2012: P=0.007\right)$, with BYDV-PAV and WSMV having the highest occurrence. At the variety performance trials where sampling intensity was consistent at each location, virus was detected in NS tillers from 13 of 15 counties sampled in 2011 and 11 of 13 counties sampled in 2012 (Fig. 3). While sampling intensity was generally lower and varied at the commercial sites, NS-infected tillers were determined at 23 of the 38 counties visited in 2011 and 6 of the 18 counties in 2012 (data not shown). Two, $31 \%$ of $\mathrm{S}$ tillers were ELISA-negative for the six virus species in the survey panel in both seasons and at both types of sites (Table 1), however, their frequency was associated with site type (variety performance trials greater than commercial sites; 2011: $P=2.2 \times 10^{-5} ; 2012: P=2.3 \times 10^{-12}$ ). Three, in general, the frequency of tillers harboring mixed infections was greater for symptomatic compared with nonsymptomatic tillers (Table $1 ; P=$ 0.02 to 0.05 ), and the frequency of mixed infections was associated with site type.

In 2012, the survey revealed that the occurrence of plants testing positive for BYDV-PAV was significantly greater $(P=0.003)$ in Art compared with Everest in plants expressing visual symptoms only (Table 2). In symptomatic plants testing positive only for WSMV, the reverse was found; half as many Art compared with Everest plants $(P=0.011)$ harbored this virus species.

Tiller grain yield and symptomology. In 2011, grain yields significantly varied by location $(P<0.0001$, Table 3$)$ regardless of symptom status, and for the most part tended to be lower in the western (Clark, Thomas, Finney, and Scott) compared with the central regions of the state (Ellis, Saline, Ellsworth, and Mitchell). Yields harvested from $S$ tillers were significantly and consistently lower than yields recovered from NS tillers at each location $(P<$ 0.0001 ), with reductions (NS versus S) ranging from 20 to $50 \%$. In 2012, regardless of symptom status the average yield obtained from Everest tillers $(0.60 \mathrm{~g}$ per head) was significantly higher $(P=$ $0.0009)$ than that for Art tillers $(0.52 \mathrm{~g}$ per head) across all locations. Similar to 2011, yields varied significantly across locations $(P<0.0001$, Table 4$)$ with the exception of NS Art plants $(P>0.52)$. Yield reductions determined for paired NS-S tillers ranged from 3 to $67 \%$ (Art) and 1 to $42 \%$ (Everest), and these reductions were significant in 18 of 22 comparisons $(P=0.0001$ to 0.03 ).
Tiller grain yield, symptomology, and virus infection status. Yields were compared among the four possible categories of plants based on symptom status (NS and $\mathrm{S}$ ) and infection status $($ ELISA-positive $=\mathrm{P}$; ELISA-negative $=\mathrm{N})$. Overall, yields varied significantly $(P<0.0001$ for both years $)$ among the four possible scenarios (Table 5). On average, $\mathrm{S}$ tillers, regardless of infection status (S-P versus S-NP), produced similar grain yields in both years $(P=0.99,0.98)$, and produced $35 \%$ lower yields $(P<$ $0.0001)$ than NS tillers harboring at least one of the virus species (NS-P) surveyed. There was a significant negative effect of virus on yield of nonsymptomatic plants (NS-P versus NS-N) in 2011, resulting in a $12.9 \%$ yield reduction. While this tendency was documented in 2012 (8.6\% difference on average), it was not statistically significant at the level of 0.05 .

Associations between tiller grain yields and BYDV or WSMV infection. General associations between infection status and grain yield were determined for BYDV and WSMV occurrence at the variety performance trial locations. Yield data were pooled across locations to make robust comparisons between yields of ELISA-negative and ELISA-positive plants regardless of symptom status. Overall, the range in the pooled yield data and the maximum yield obtained from ELISA-positive plants for either virus species was lower compared with that of ELISA-negative plants across the state (Fig. 4). Outlying data falling below the 10th percentile for ELISA-negative plants for either virus species indicated other factors associated with low grain yields for those tillers. A generalized linear model analysis revealed that average grain yields from plants infected only with BYDV were 22 and $15 \%$ lower compared with yields obtained for ELISA-negative plants in 2011 $(P<0.0001)$ and $2012(P<0.011)$, respectively. Plants infected only with WSMV averaged $33 \%$ lower yields $(P<0.0001)$ in 2012 , with no apparent significant contribution to yield loss in $2011(P=$ 0.98). Our findings support the hypothesis that natural occurrence of these two virus species can contribute to wheat yield losses in Kansas.

Further dissection of the association between infection status and tiller grain yield was performed to compare the two targeted varieties (Art and Everest) in 2012. The difference in average grain yields between BYDV-PAV-positive and ELISA-negative tillers was marginally significant $(P=0.09)$ for either Art or Everest; expressed as percent reductions, Art (13\%) and Everest (14\%) were comparable. Average yield differences between WSMV-positive and -negative plants for either variety were significant $(P=0.016$

TABLE 1. Spring infection incidence (\%) of nonsymptomatic (NS) and symptomatic (S) tillers that tested positive for virus in surveys conducted at Kansas Agricultural Experiment Station variety performance trials and commercial field sites across Kansas in two consecutive seasons

\begin{tabular}{|c|c|c|c|c|c|c|c|c|c|}
\hline \multirow[b]{2}{*}{ Site type } & \multirow[b]{2}{*}{ Year } & \multirow[b]{2}{*}{$\begin{array}{l}\text { Symptom } \\
\text { status }^{\mathrm{u}}\end{array}$} & \multirow[b]{2}{*}{$\begin{array}{c}\text { Number of tillers } \\
\text { sampled }\end{array}$} & \multicolumn{4}{|c|}{$\%$ Plants testing positive for } & \multirow[b]{2}{*}{$\begin{array}{c}\text { Mixed } \\
\text { infections }^{w}\end{array}$} & \multirow[b]{2}{*}{$\begin{array}{l}\text { Species combinations in mixed } \\
\text { infections }^{\mathrm{x}}\end{array}$} \\
\hline & & & & $\begin{array}{l}\text { At least one of } \\
\text { six in panel }\end{array}$ & BYDV-PAV & WSMV & HPV & & \\
\hline \multirow{3}{*}{ Variety trials } & 2011 & NS & 285 & $23(66 / 285)$ & $20^{y}$ & 3 & 0.4 & 0.7 & $\mathrm{~B}+\mathrm{W}$ \\
\hline & 2012 & NS & 260 & $12(31 / 260)$ & 9 & 2 & 1 & 0.4 & $\mathrm{~B}+\mathrm{W}$ \\
\hline & 2012 & $\mathrm{~S}$ & 260 & $55(143 / 260)$ & 41 & 14 & 2 & 2.3 & $\mathrm{~B}+\mathrm{W}, \mathrm{W}+\mathrm{H}$ \\
\hline Commercial & 2011 & NS & 93 & $53(49 / 93)$ & 23 & 25 & 17 & 14.0 & $\mathrm{~B}+\mathrm{W}, \mathrm{W}+\mathrm{H}, \mathrm{B}+\mathrm{W}+\mathrm{H}+\mathrm{C}$ \\
\hline
\end{tabular}

u NS and S tillers from plants sampled from a 30- $\mathrm{m}^{2}$ area within border rows forming the perimeter of variety performance trial sites in 15 counties in 2011 and from variety performance trial test plots (2-m wide $\times 8-\mathrm{m}$ long) of cultivars Art and Everest in 13 counties in 2012, and within commercial fields from 38 and 18 counties in spring 2011 and 2012, respectively.

${ }^{v}$ Percentage of plants testing positive for at least one of the six virus species in the ELISA test panel: Barley yellow dwarf virus (BYDV-PAV), Wheat streak mosaic virus (WSMV), High plains virus (HPV), Soilborne wheat mosaic virus (SBWMV), Wheat spindle streak mosaic virus (WSSMV), and Cereal yellow dwarf virus (CYDV-RPV).

w Percentage of plants testing positive for more than one of the six virus species in the ELISA test panel.

$\times \mathrm{B}=\mathrm{BYDV}-\mathrm{PAV}, \mathrm{W}=\mathrm{WSMV}, \mathrm{H}=\mathrm{HPV}, \mathrm{SB}=\mathrm{SBWMV}, \mathrm{SS}=\mathrm{WSSMV}$, and $\mathrm{C}=\mathrm{CYDV}-\mathrm{RPV}$.

y Values indicate percentage of plants testing positive for the virus species indicated, regardless of co-occurrence with other virus species in the test panel.

${ }^{z}$ Equal number of NS and S tillers from individual plants was not achieved at commercial field sites due, in part, to difficulty in locating NS plants in close range to S plants from selected locations in 2012. 
and $P<0.0001$, respectively), however, average reductions were comparable between Art (33\%) and Everest (34\%). These findings point to other biological or abiotic factors that contribute to the greater grain yields in Everest compared with Art during the growing season.

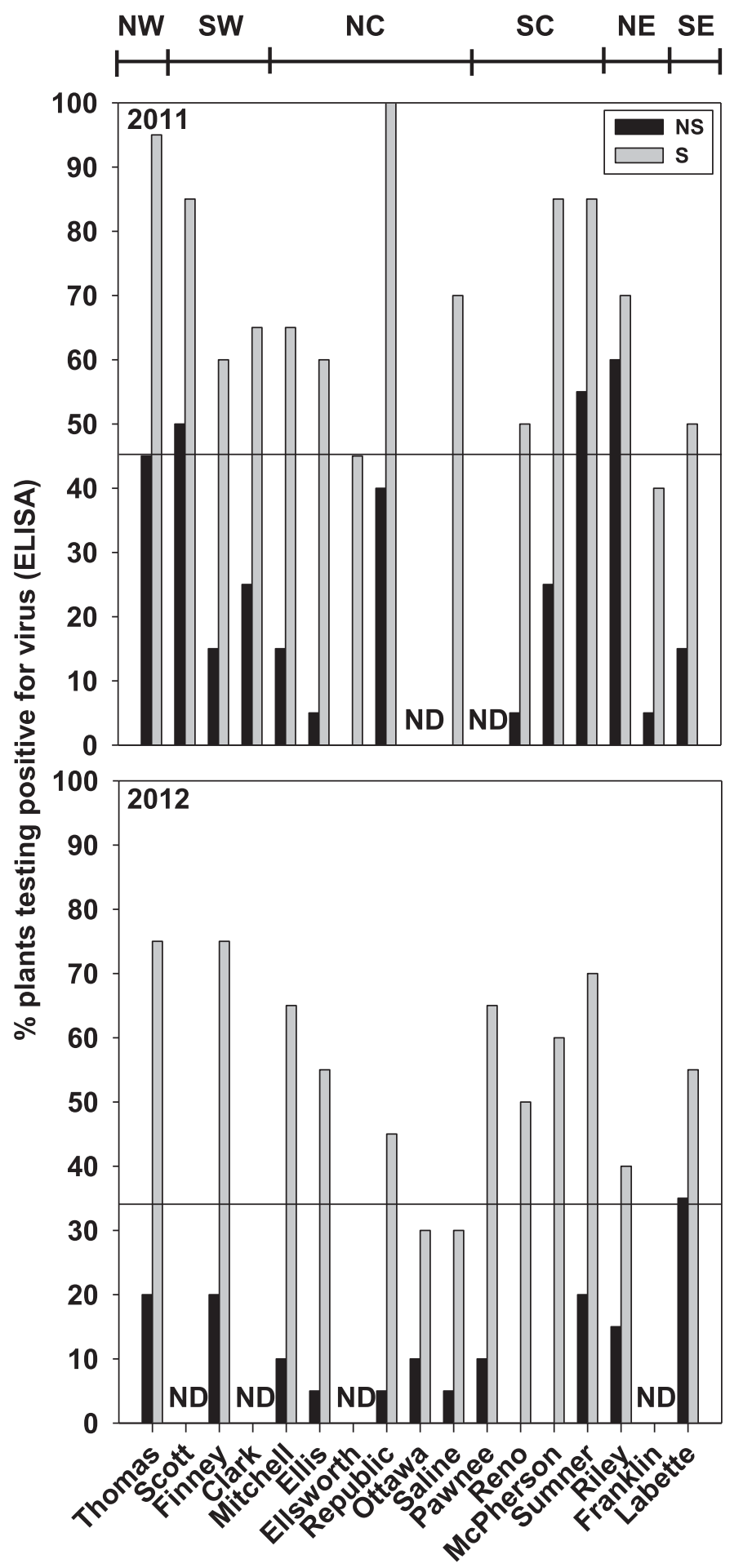

\section{Variety trial locations (counties)}

Fig. 3. Occurrence of wheat virus infection in nonsymptomatic (NS) and symptomatic (S) plants collected from Kansas Agricultural Experiment Station variety trials in 17 counties over two consecutive seasons. The solid horizontal line indicates the average percentage of ELISA-positive samples determined for each season regardless of symptom status. $\mathrm{ND}=$ not determined. $\mathrm{NW}=$ northwest, $\mathrm{SW}=$ southwest, $\mathrm{NC}=$ north-central, $\mathrm{SC}=$ south-central, $\mathrm{NE}=$ northeast, and $\mathrm{SE}=$ southeast.

\section{DISCUSSION}

Both BYDV-PAV and WSMV were prevalent and widespread in our statewide survey. In contrast to a spring 2008 winter wheat survey that reported $6 \%$ of samples obtained from symptomatic plants in Kansas tested positive for BYDV-PAV (Burrows et al. 2009), we found that BYDV-PAV was the predominant species in the panel, with nearly one-third (32.6\%) of collected tillers (NS and $\mathrm{S}$ combined) testing positive for the virus. The apparent difference in the prevalence of this virus species between this and the present study was likely due to differences in sampling intensity $(n=53$ in 2008 versus $n=768$ in 2011 and $n=680$ in 2012), crop-reporting regions represented (unreported Kansas regional locations in the 2008 study) and seasonal environmental conditions that favor vector populations and disease development. Previously reported Great Plains surveys including Kansas commercial wheat fields

TABLE 2. Occurrence of Barley yellow dwarf virus-PAV (BYDV-PAV) and Wheat streak mosaic virus (WSMV) in nonsymptomatic (NS) and symptomatic (S) tillers ${ }^{\mathrm{w}}$ of wheat cultivars Art and Everest

\begin{tabular}{|c|c|c|c|c|c|c|}
\hline \multirow[b]{3}{*}{ Virus species tested } & \multicolumn{6}{|c|}{ Symptom status } \\
\hline & \multicolumn{3}{|c|}{ NS } & \multicolumn{3}{|c|}{$\mathrm{S}$} \\
\hline & Art & Everest & $P$ value & Art & Everest & $P$ value \\
\hline Any of $\operatorname{six}^{x}$ & $17^{y}$ & 8 & $0.125^{\mathrm{z}}$ & 57 & 51 & 0.059 \\
\hline BYDV-PAV only & 14 & 6 & 0.198 & 47 & 30 & 0.003 \\
\hline WSMV only & 2 & 3 & 0.653 & 11 & 21 & 0.011 \\
\hline
\end{tabular}

${ }^{\mathrm{w}}$ Equal numbers of NS and S tillers (one tiller per plant, 10 pairs of NS-S tillers $=20$ tillers per variety per location) were sampled from variety performance test plots (2-m wide by $8-\mathrm{m}$ long) of cultivars Art and Everest in spring 2012 from 11 variety performance trial locations (i.e., 11 counties) for virus species determination by ELISA.

${ }^{x}$ ELISA-positive, regardless of species determined from test panel of six.

y Values are $\%$ tillers sampled in total from all 11 locations for each symptom status by variety combination $(n=110$ tillers per symptom status per variety).

z Two-tailed $P$ value determined from Fisher's exact test of independence performed on frequency data (i.e., total number of virus-positive and total number of virus-negative) in $2 \times 2$ contingency tables (infection status $[+/-] \times$ variety [Art/Everest]) to determine if tiller infection status was independent of variety (null hypothesis). The analyses were performed for NS and S tillers separately as shown.

TABLE 3. Grain yield of single heads harvested from paired nonsymptomatic (NS) and symptomatic (S) wheat tillers in Kansas Agricultural Experiment Station variety performance trial locations in 2011

\begin{tabular}{lllr}
\hline & \multicolumn{3}{c}{ Average seed weight per head $(\mathrm{g})^{\mathrm{x}}$} \\
\cline { 2 - 4 } Location (county) & NS tillers & S tillers & NS versus $\mathrm{S}^{\mathrm{y}}$ \\
\hline Mitchell & $1.12 \mathrm{a}^{\mathrm{z}}$ & $0.72 \mathrm{a}$ & $<0.0001$ \\
Ellsworth & $1.12 \mathrm{a}$ & $0.64 \mathrm{ab}$ & $<0.0001$ \\
Saline & $1.03 \mathrm{ab}$ & $0.60 \mathrm{abc}$ & $<0.0001$ \\
Franklin & $0.88 \mathrm{abc}$ & $0.60 \mathrm{abc}$ & 0.0006 \\
Ellis & $0.87 \mathrm{abcd}$ & $0.62 \mathrm{ab}$ & 0.0012 \\
Riley & $0.86 \mathrm{abcd}$ & $0.45 \mathrm{abcd}$ & $<0.0001$ \\
Scott & $0.73 \mathrm{bcde}$ & $0.35 \mathrm{de}$ & $<0.0001$ \\
Labette & $0.61 \mathrm{cde}$ & $0.41 \mathrm{bcd}$ & 0.0001 \\
Finney & $0.59 \mathrm{de}$ & $0.34 \mathrm{de}$ & $<0.0001$ \\
Thomas & $0.57 \mathrm{e}$ & $0.36 \mathrm{~d}$ & $<0.0001$ \\
Clark & $0.55 \mathrm{e}$ & $0.24 \mathrm{e}$ & $<0.0001$
\end{tabular}

Type III tests of fixed effects

\begin{tabular}{lccc}
\hline Source of variation & df & $F$ value & $P>F$ \\
\hline Location & 10 & 30.10 & $<0.0001$ \\
Symptom (location) & 11 & 28.50 & $<0.0001$ \\
\hline
\end{tabular}

x Values represent $n=20$ tillers from 20 plants ( 1 tiller per plant) for each location-symptom status (NS or S).

y $P$ values adjusted for multiple comparisons (Tukey-Kramer).

$\mathrm{z}$ Means within symptom status followed by different letters indicate significant differences between locations at $P<0.05$. 
reported a high occurrence of symptomatic WSMV-infected plants (Burrows et al. 2009; Byamukama et al. 2013), therefore it was not surprising that we found $42 \%$ of tillers tested positive for this virus at commercial sites over the two-year survey. It is noteworthy that one of the previously published regional surveys (Byamukama et al. 2013) that was conducted during one of our survey years reported a considerably greater proportion $(91 \%)$ of WSMV-positive plants sampled from Kansas commercial fields in the spring $2011(n=335$ from 22 counties) compared with the present study (Table $1,52 \%$ of $\mathrm{S}$ plants tested positive for WSMV in commercial fields in spring 2011). Since the aim of the regional survey was to document the

TABLE 4. Grain yield of single heads harvested from paired nonsymptomatic (NS) and symptomatic (S) wheat tillers in Kansas Agricultural Experiment Station variety performance trial test plots in 2012

\begin{tabular}{llllc}
\hline \multirow{2}{*}{ Variety } & & \multicolumn{3}{c}{ Average seed weight per head $(\mathrm{g})^{\mathrm{x}}$} \\
\cline { 3 - 5 } Art & Location (county) & NS plants & S plants & NS versus S \\
\hline & Finney & $0.87 \mathrm{a}^{\mathrm{z}}$ & $0.47 \mathrm{a}$ & 0.008 \\
& Labette & $0.82 \mathrm{a}$ & $0.44 \mathrm{a}$ & 0.0001 \\
Sumner & $0.79 \mathrm{a}$ & $0.42 \mathrm{a}$ & 0.0001 \\
& Franklin & $0.78 \mathrm{a}$ & $0.27 \mathrm{ab}$ & $<0.0001$ \\
Republic & $0.77 \mathrm{a}$ & $0.44 \mathrm{a}$ & 0.0008 \\
& Riley & $0.68 \mathrm{a}$ & $0.43 \mathrm{a}$ & 0.01 \\
Mitchell & $0.61 \mathrm{a}$ & $0.32 \mathrm{ab}$ & 0.0001 \\
& Reno & $0.59 \mathrm{a}$ & $0.46 \mathrm{a}$ & 0.22 \\
Saline & $0.58 \mathrm{a}$ & $0.18 \mathrm{~b}$ & $<0.0001$ \\
& McPherson & $0.56 \mathrm{a}$ & $0.34 \mathrm{ab}$ & 0.0005 \\
Thomas & $0.45 \mathrm{a}$ & $0.25 \mathrm{ab}$ & 0.0006 \\
& Republic & $1.00 \mathrm{a}$ & $0.58 \mathrm{a}$ & 0.0009 \\
& Finney & $0.95 \mathrm{a}$ & $0.60 \mathrm{a}$ & 0.01 \\
& Sumner & $0.77 \mathrm{ab}$ & $0.66 \mathrm{a}$ & 0.41 \\
Riley & $0.73 \mathrm{ab}$ & $0.51 \mathrm{a}$ & 0.02 \\
& Labette & $0.72 \mathrm{ab}$ & $0.40 \mathrm{ab}$ & 0.0003 \\
& Franklin & $0.71 \mathrm{ab}$ & $0.48 \mathrm{a}$ & 0.009 \\
Mitchell & $0.69 \mathrm{ab}$ & $0.49 \mathrm{a}$ & 0.03 \\
& McPherson & $0.68 \mathrm{ab}$ & $0.41 \mathrm{ab}$ & 0.0008 \\
& Reno & $0.61 \mathrm{ab}$ & $0.58 \mathrm{a}$ & 0.59 \\
Saline & $0.51 \mathrm{ab}$ & $0.44 \mathrm{ab}$ & 0.29 \\
Thomas & $0.42 \mathrm{~b}$ & $0.21 \mathrm{~b}$ & $<0.0001$ \\
& & &
\end{tabular}

Type III tests of fixed effects

\begin{tabular}{lrcr}
\hline Source of variation & df & $F$ value & $P>F$ \\
\hline Location & 10 & 8.43 & $<0.0001$ \\
Variety & 1 & 11.34 & 0.0009 \\
Location $\times$ variety & 10 & 0.93 & 0.5083 \\
Symptom (location $\times$ variety) & 22 & 13.19 & $<0.0001$ \\
\hline
\end{tabular}

$\times$ Values represent $n=10$ tillers from 10 plants (1 tiller per plant) per symptom status (NS or S) per location-variety.

y $P$ values adjusted for multiple comparisons (Tukey-Kramer).

z Means within variety-symptom status followed by different letters indicate significant differences between locations at $P<0.05$. occurrence of miteborne viruses only, tissue samples were selected based on symptoms typically associated with these viruses, thereby increasing the likelihood of detecting WSMV in their sampling pool. In our case, the collection of symptomatic samples included in the Kansas survey represented tillers exhibiting an array of viruslike symptoms and fewer samples were collected in comparison ( $n=105$ from 38 counties in spring 2011).

Surveying two types of managed sites across the state revealed fundamental differences in virus species occurrence. In both seasons of the survey, occurrence of WSMV-positive plants was

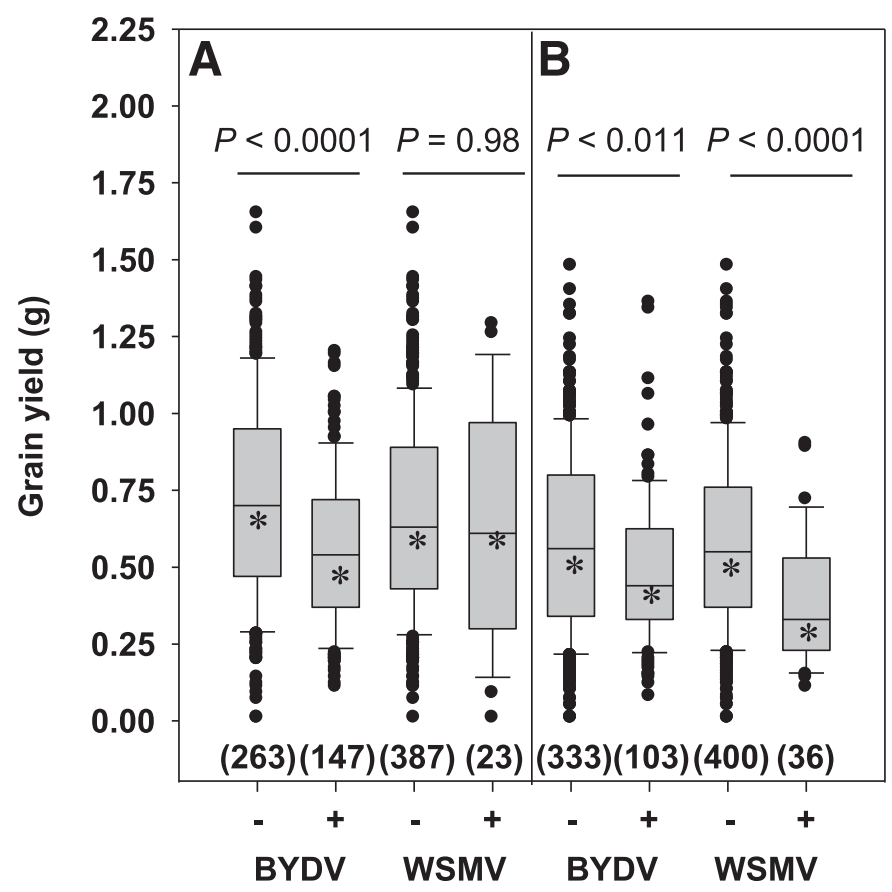

Infection status and virus species

Fig. 4. Grain yield of tagged heads of tillers singly infected with Barley yellow dwarf virus-PAV (BYDV-PAV) or Wheat streak mosaic virus (WSMV) in Kansas Agricultural Experiment Station variety performance trial locations in A, 2011 and B, 2012. Data were pooled across all locations for nonsymptomatic and symptomatic plants (numbers in parentheses indicates number of heads determined for each virus $\times$ infection status combination). $-=$ ELISA-negative, $+=$ ELISA-positive. The standard method of linear interpolation in SigmaPlot v. 10.0 was used to compute the percentile values for data distributions illustrated by box (25th to 75 th percentile values, median line depicted and mean designated by *) and whiskers (10th and 90th percentile values) plots. Data that occurred outside the computed 10th and 90th percentile values were considered outlying data and are depicted as solid points.

TABLE 5. Analysis of grain yields for four possible symptom-infection scenarios in Kansas Agricultural Experiment Station variety performance trials across the state in two consecutive seasons

\begin{tabular}{|c|c|c|c|c|c|}
\hline \multirow[b]{2}{*}{ Symptom status } & \multirow[b]{2}{*}{ Infection status ${ }^{\mathrm{x}}$} & \multicolumn{2}{|c|}{ Number of tiller heads ${ }^{y}$} & \multicolumn{2}{|c|}{ Seed weight per head (g) } \\
\hline & & 2011 & 2012 & 2011 & 2012 \\
\hline \multirow[t]{2}{*}{ Symptomatic (S) } & Positive $(\mathrm{P})$ & 131 & 115 & $0.48 \pm 0.02$ & $0.42 \pm 0.02$ \\
\hline & Not positive (NP) & 79 & 99 & $0.48 \pm 0.03$ & $0.42 \pm 0.02$ \\
\hline & Not positive (NP) & 154 & 188 & $0.85 \pm 0.02$ & $0.70 \pm 0.02$ \\
\hline \multirow[t]{2}{*}{ Pairwise contrasts } & S-P versus S-NP & & & $P=0.99$ & $P=0.98$ \\
\hline & S-P versus NS-P & & & $P<0.0001$ & $P<0.0001$ \\
\hline
\end{tabular}

x Determined by ELISA.

y A total of 11 out of 15 and 11 out of 13 trial locations (i.e., one location per county) in 2011 and 2012, respectively, were sampled for 20 tillers per S and NS. Total number of tillers sampled $=20 \times 11$ locations $=220$ tillers per symptom status ( $\mathrm{S}$ or NS), unless replicate heads were lost prior to grain yield determination (missing data ranged from two to six heads per symptom-infection status combination).

z No missing data. 
lower at the variety performance trial sites compared with the commercial sites. Likewise, the two soilborne viruses (SBWMV and WSSMV) were detected either singly or in mixed infections with other virus species in commercial fields only. Possibly reflecting the overall prevalence of the miteborne and soilborne viruses in these commercial fields, mixed infections were more common at the commercial sites. One possible explanation for these site type differences may point to the widespread adoption of best management practices by KAES superintendents that manage the variety performance trials. Integrated management practices at these sites include cultural strategies that have been shown to reduce vector performance and prevalence, such as delayed planting to avoid peak vector populations or removal of volunteer wheat that may serve as "green bridge" reservoirs that harbor viruliferous vectors, notably WCM, between spring and fall cropping systems (Jiang et al. 2005). In the case of soilborne virus diseases, superintendents likely avoid planting in areas known to have a history of SBWMV or WSSMV. Also, these trials are test sites for elite wheat lines with varying genetic resistance to viruses, and a concerted effort to develop and evaluate resistance to diseases including WSM and soilborne viral diseases has been a priority for more than 30 years at these sites, with BYD resistance lagging behind (Bockus et al. 2001). Our findings indicate that the best options for managing vector-borne diseases in the state are likely practiced robustly by KAES superintendents and that more integrated control options currently exist for the mite-borne and soilborne virus diseases compared with BYD.

A substantial proportion of tillers testing positive for BYDV-PAV or WSMV was NS, a finding that underscores the importance of sampling criteria to more accurately estimate virus occurrence in wheat fields. The occurrence of these NS virus-infected plants may be a consequence of several biological and environmental factors that influence disease development and symptom expression, such as plant maturity at time of inoculation (Hunger et al. 1992; Perry et al. 2000). Lack of visual symptoms in the present study may have resulted from late spring infections (after jointing), allowing less time for virus to accumulate systemically to titers that contribute to discerning symptoms. Our findings also indicate that NS plants harboring these virus species were physiologically impaired in the absence of visible virus-associated symptoms, however to a lesser extent than S plants. Validating the presence of viruses in NS plants may provide an additional parameter toward estimating grain losses associated with wheat virus diseases.

The survey also revealed a proportion of ELISA-negative tissue samples obtained from $S$ tillers. One explanation for this finding could be tissue integrity at time of sampling. In both 2011 and 2012, Kansas wheat experienced persistently dry conditions throughout the state during March and April and temperatures reached record highs in February through March in 2012, causing the crop to develop and mature 3 weeks sooner than average in the spring (http://www.nass.usda.gov/Statistics_by_State/Kansas/ Publications/Crops/whthist.pdf). The southwest region of Kansas experienced drought conditions in 2012, and in May, the state experienced record high temperatures. It is possible that poor tissue quality in 2012 from fields experiencing drought condition and high temperatures may have obscured assessment of symptoms or reduced efficiency of plant sap extraction of virus requisite for the ELISA protocol. Another likely explanation for ELISA-negative symptomatic tillers was the presence of other virus species not included in the panel. For example, other yellow dwarf viruses (YDV) not detected by the BYDV-PAV detection kit may have contributed to the observed symptoms typical of YDVs. Likewise, TriMV, a WCM-borne virus that occurs in Kansas wheat fields and causes similar symptoms, may have been associated with these symptomatic plants. Other wheatinfecting viruses that have been reported in Kansas, such as American wheat striate mosaic virus (Seifers et al. 1995) and Wheat yellow head virus (Seifers et al. 2005), may have contributed to symptomology exhibited by these plants. In the present study, the panel of selected viruses of economic importance enabled us to efficiently perform the surveys using commercially available antibodies and similar methodology (DAS- and TAS-ELISA). Future studies include examination of other wheat virus species using both serological and PCR-based methods of detection.

Visually surveying winter wheat fields in the spring to identify and tag replicate pairs of S and NS tillers soon after heading within a defined sampling space at multiple locations provided a direct means for examining associations between virus infection status and grain yields of individual tillers. The negative impact of naturally occurring viruses in winter wheat, most notably BYDV and WSMV, on tiller grain yield was documented by either relying on visual symptoms typically associated with the test panel species, or by direct coupling of the presence of virus in plant tissue with grain yields from the tagged tillers. Conventional field plot approaches to quantifying the effect of WSMV or BYDV on plant yields have relied on either comparing yields of plants mechanically inoculated (WSMV) or exposed to lab-reared viruliferous aphids (BYDV) to noninoculated plants under field conditions in standard field plot designs, or by comparing yields of insecticide-treated controls, as in the case for grain aphids, to nontreated plants with the expectation that nontreated controls will produce lower yields provided the prevalence of inoculative naturally occurring viruliferous vectors. Both of these traditional approaches have revealed the negative impact of WSMV and BYDV on grain yields in field trials replicated at a few locations in other states (McKirdy et al. 2002; Miller et al. 2014; Perry et al. 2000). The outcome of the present survey and direct coupling of tiller grain yield and infection status may lead to future studies toward developing and testing new sources of BYD resistance and tolerance at field sites across the state.

The potentially added value of our paired S-NS tiller approach could offer a complementary ecological approach to revealing the effects of naturally occurring viruses on host health in traditional agronomic field-plot size sampling space or in designated areas encompassed by native grasslands in Kansas, all in the context of variable growing conditions influenced by rainfall (Prism precipitation maps: http://www.wrcc.dri.edu/precip.html) and temperature gradients across Kansas and the Great Plains (Lauenroth and Burke 1995). The extensive statewide sampling coverage of the present study also likely captured the diversity of vector populations and virus haplotypes prevalent to a particular region, and provides opportunities for future studies of vector species composition and virus genetic diversity in Kansas.

\section{ACKNOWLEDGMENTS}

This research was funded by a grant from Heartland Plant Innovations, Inc. We also thank F. Chumley for insightful discussions about the project. This is contribution 16-139-J from the Kansas Agricultural Experiment Station.

\section{LITERATURE CITED}

Appel, J., DeWolf, E., Bockus, W., and Todd, T. 2014. Preliminary 2014 Kansas wheat disease loss estimates. Kansas Cooperative Plant Disease Survey Report. http://agriculture.ks.gov/docs/default-source/PP-Disease-Reports-2014/ 2014-ks-wheat-disease-loss-estimates.pdf

Banks, P., Davidson, J., Bariana, H., and Larkin, P. 1995. Effects of Barley yellow dwarf virus on the yield of winter wheat. Aust. J. Agric. Res. 46: 935-946.

Bockus, W. W., Appel, J. A., Bowden, R. L., Fritz, A. K., Gill, B. S., Martin, T. J., Sears, R. G., Seifers, D. L., Brown-Guedira, G. L., and Eversmeyer, M. G. 2001. Success stories: Breeding for wheat disease resistance in Kansas. Plant Dis. 85:453-461.

Budge, G. E., Ratti, C., Rubies-Autonell, C., Lockley, D., Bonnefoy, M., Vallega, V., Pietravalle, S., and Henry, C. M. 2008. Response of UK winter wheat cultivars to Soil-borne cereal mosaic and Wheat spindle streak mosaic viruses across Europe. Eur. J. Plant Pathol. 120:259-272.

Burrows, M., Franc, G., Rush, C., Blunt, T., Ito, D., Kinzer, K., Olson, J., O’Mara, J., Price, J., Tande, C., Ziems, A., and Stack, J. 2009. 
Occurrence of viruses in wheat in the Great Plains region, 2008. Online. Plant Health Progress doi:10.1094/PHP-2009-0706-01-RS

Byamukama, E., Seifers, D. L., Hein, G. L., De Wolf, E., Tisserat, N. A., Langham, M. A. C., Osborne, L. E., Timmerman, A., and Wegulo, S. N. 2013. Occurrence and distribution of Triticum mosaic virus in the Central Great Plains. Plant Dis. 97:21-29.

Campbell, L. G., Heyne, E. G., Gronau, D. M., and Niblett, C. 1975. Effect of Soilborne wheat mosaic virus on wheat yield. Plant Dis. Rep. 59:472-476.

De Wolf, E. D., Bockus, W. W., and Whitworth, J. R. 2014. Wheat Variety Disease and Insect Ratings 2014. Kansas Cooperative Extension Service Publication MF-991.

Domier, L. L. 2012. Pages 1045-1053 in: Family- Luteoviridae, in Virus Taxonomy, 9th Ed. M. Q. K. Andrew, L. Elliot, J. A. Michael, and E. B. Carstens, eds. Elsevier, San Diego, CA.

Garrett, K. A., Dendy, S. P., Power, A. G., Blaisdell, G. K., Alexander, H. M., and McCarron, J. K. 2004. Barley yellow dwarf disease in natural populations of dominant tallgrass prairie species in Kansas. Plant Dis. 88:574.

Gaunce, G. M., and Bockus, W. W. 2015. Estimating yield losses due to barley yellow dwarf on winter wheat in Kansas using disease phenotypic data. Online. Plant Health Progress doi:10.1094/PHP-RS-14-0039

Herbert, D. A., Jr., Stromberg, E. L., Chappell, G. F., and Malone, S. M. 1999. Reduction of yield components by barley yellow dwarf infection in susceptible winter wheat and winter barley in Virginia. J. Prod. Agric. 12:105-109.

Hunger, R. M., Sherwood, J. L., Evans, C. K., and Montana, J. R. 1992. Effects of planting date and inoculation date on severity of wheat streak mosaic in hard red winter wheat cultivars. Plant Dis. 76:1056-1060.

Jiang, W., Garrett, K. A., Peterson, D. E., Harvey, T. L., Bowden, R. L., and Fang, L. 2005. The window of risk for emigration of Wheat streak mosaic virus varies with host eradication method. Plant Dis. 89:853-858.

Kanyuka, K., Lovell, D. J., Mitrofanova, O. P., Hammond-Kosack, K., and Adams, M. J. 2004. A controlled environment test for resistance to Soilborne cereal mosaic virus (SBCMV) and its use to determine the mode of inheritance of resistance in wheat cv. Cadenza and for screening Triticum monococcum genotypes for sources of SBCMV resistance. Plant Pathol. 53: 154-160.

Lauenroth, W. K., and Burke, I. C. 1995. Great Plains climate variability. Pages 237-249 in: Encyclopedia of Environmental Biology. W. A. Nierenberg, ed. Vol. 2. Academic Press Inc., San Diego, CA.

Lingenfelser, J., Bockus, B., DeWolf, E., Fritz, A., Knapp, M., Whitworth, J., Heer, W., Kimball, J., Nelson, R., Maddux, L., Evans, P., Kusel, K., Martin, T. J., Seaman, C., Schlegel, A., Spangler, M., Chen, M., Chen, R., McLaughlin, L., Knopf, J., Miller, R., and Shroyer, J. 2011. Performance Tests with Winter Wheat Varieties. Kansas State University Agricultural Experiment Station and Cooperative Extension Service Report of Progress No. 1054.

Lister, R. M., and Ranieri, R. 1995. Distribution and economic importance of Barley Yellow Dwarf. Pages 29-53 in: Barley Yellow Dwarf 40 Years of
Progress. C. J. D'Arcy and P. Burnett, eds. The American Phytopathological Society, St. Paul, MN.

Liu, F., Wang, X., Liu, Y., Xie, J., Gray, S. M., Zhou, G., and Gao, B. 2007. A Chinese isolate of Barley yellow dwarf virus-PAV represents a third distinct species within the PAV serotype. Arch. Virol. 152: $1365-1373$.

McKirdy, S. J., Jones, R. A. C., and Nutter, F. W. 2002. Quantification of yield losses caused by Barley yellow dwarf virus in wheat and oats. Plant Dis. 86: 769-773.

Miller, W. A., and Rasochová, L. 1997. Barley yellow dwarf viruses. Annu. Rev. Phytopathol. 35:167-190.

Miller, Z., Menalled, F., Ito, D., Moffet, M., and Burrows, M. 2014. Impacts of crop variety and time of inoculation on the susceptibility and tolerance of winter wheat to Wheat streak mosaic virus. Plant Dis. 98:1060-1065.

Pakdel, A., Afsharifar, A., Niazi, A., Almasi, R., and Izadpanah, K. 2010. Distribution of cereal luteoviruses and molecular diversity of BYDV-PAV isolates in Central and Southern Iran: Proposal of a new species in the genus Luteovirus. J. Phytopathol. 158:357-364.

Perry, K. L., Kolb, F. L., Sammons, B., Lawson, C., Cisar, G., and Ohm, H. 2000. Yield effects of Barley yellow dwarf virus in soft red winter wheat. Phytopathology 90:1043-1048.

Price, J. A., Workneh, F., Evett, S. R., Jones, D. C., Arthur, J., and Rush, C. M. 2010. Effects of Wheat streak mosaic virus on root development and wateruse efficiency of hard red winter wheat. Plant Dis. 94:766-770.

Seifers, D. L., Harvey, T. L., and Bowden, R. L. 1995. Occurrence and symptom expression of American wheat striate mosaic virus in wheat in Kansas. Plant Dis. 79:853-858.

Seifers, D. L., Harvey, T. L., Martin, T. J., Haber, S., She, Y.-M., Ens, W., Standing, K. G., Salomon, R., and Gera, A. 2005. Association of a virus with wheat displaying yellow head disease symptoms in the Great Plains. Plant Dis. 89:888-895.

Seifers, D. L., Martin, T. J., and Fellers, J. P. 2010. Occurrence and yield effects of wheat infected with Triticum mosaic virus in Kansas. Plant Dis. 95:183-188.

Shahwan, I. M., and Hill, J. P. 1984. Identification and occurrence of Wheat streak mosaic virus in winter-wheat in Colorado and its effects on several wheat cultivars. Plant Dis. 68:579-581.

Svanella-Dumas, L., Candresse, T., Hullé, M., and Marais, A. 2013. Distribution of Barley yellow dwarf virus-PAV in the Sub-Antarctic Kerguelen Islands and characterization of two new luteovirus species. PLoS One 8: e67231.

Vallega, V., Rubies-Autonell, C., and Ratti, C. 2003. Reaction of durum wheat cultivars to mixed SBWMV and WSSMV infection in central Italy. Phytopathol. Mediterr. 42:177-182.

Velandia, M., Rejesus, R. M., Jones, D. C., Price, J. A., Workneh, F., and Rush, C. M. 2010. Economic impact of Wheat streak mosaic virus in the Texas High Plains. Crop Prot. 29:699-703. 